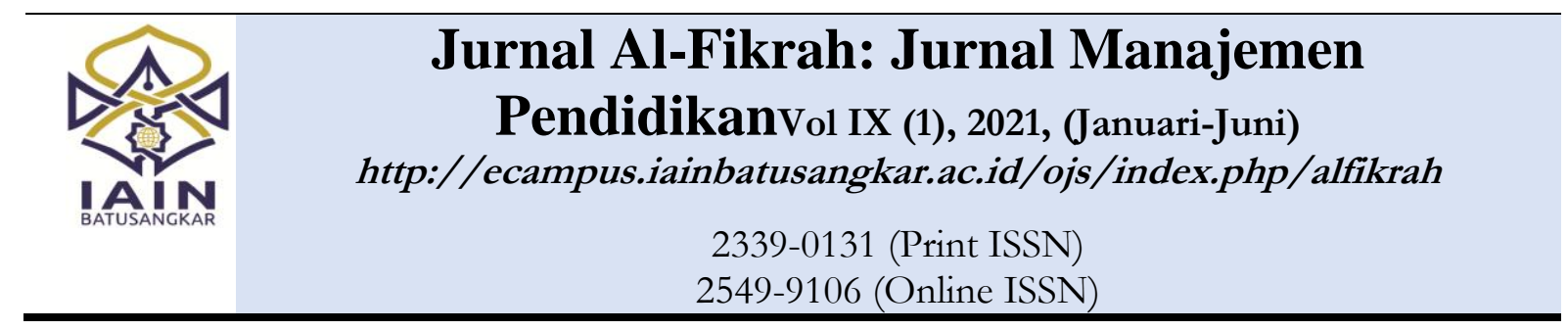

Leadership of School Principal in Improving the Academic Quality of Elementary School Students during the Covid-19 Pandemic

\title{
Kepemimpinan Kepala Sekolah Dalam Meningkatkan Mutu Akademik Siswa SD di Masa Pandemi Covid-19
}

Received:14-01-2021; Revised:08-06-2021; Accepted:17-06-2021

\author{
Kurnia Arumsari ${ }^{1}$, Enung Hasanah ${ }^{2 *}$ \\ Magister Manajemen Pendidikan, Universitas Ahmad Dahlan, \\ Jl. Pramuka No.42, Pandeyan, Kec. Umbulharjo, Kota Yogyakarta 55161 \\ E-mail : enung.hasanah@mp.uad.ac.id \\ *) Corresponding Author
}

\begin{abstract}
2000
Abstract: The Covid-19 pandemic has made changes in all fields, including education. Everyone in the field of education is required to do online learning. There are many obstacles in online learning, one of which is the decline of the academic quality of students. The purpose of this study is to find out the best practices of leadership implemented by the Principal of SD Mubammadiyah Karangkajen 4 Yogyakarta in improving the academic quality of students during the Covid-19 pandemic. The researchers used qualitative method and the data of the research were collected hrough observation and interviews with school principal and the teachers. The results of this study showed that the principal opened a learning consultation service in schools. Beside the school continued implementing the health protocols recommended by the government and several requirements such as teachers and students must be in good health, not from outside the city, and no family bas been affected by COVID-19. The existence of study consultations at schoolmade thes tudents more enthusiastic in learning, more responsible in doing their tasks, their academic scores increase.
\end{abstract}

Keywords: Leadership, principal, academic quality, covid-19 pandemic

Abstrak: Pandemi Covid-19 membuat perubahan disegala bidang, tidak terkecuali bidang pendidikan. Semua yang berada dibidang pendidikan wajib melakukan pembelajaran secara daring. Banyak terjadi kendala pada pembelajaran daring, salah satunya adalah menurunnya mutu akademik siswa. Tujuan penelitian ini yaitu untuk mengetahui best practices kepemimpinan kepala sekolah SD Muhammadiyah Karangkajen 4 Yogyakarta untuk meningkatkan mutu akademik siswa selama masa pandemi Covid-19. Peneliti menggunakan metode kualitatif dan pengumpulan data menggunakan teknik observasi dan wawancara dengan kepala sekolah dan guru-guru. Hasil dari penelitian ini, yaitu kepala sekolah membuka layanan konsultasi belajar di sekolah. Dengan tetap melaksanakan protokol kesehatan yang dianjurkan oleh pemerintah dan beberapa persyaratan seperti guru dan siswa harus dalam kondisi sehat, tidak dari luar kota, dan keluarga tidak ada yang terkena covid-19. Terbukti dengan adanya konsultasi belajar di sekolah, 
siswa lebih semangat dalam belajar, nilai akademiknya meningkat lagi dan siswa lebih bertanggungjawab dalam mengerjakan tugas-tugasnya.

Kata Kunci: Kepemimpinan, kepala sekolah, mutu akademik, pandemi covid-19

\section{PENDAHULUAN}

Oovid-19 adalah penyakit menular yang disebabkan oleh virus corona. Virus baru ini terjadi pertama kali di Wuhan, China pada Desember 2019. Virus corona ini menyerang di seluruh penjuru dunia, termasuk di Indonesia. Pada awal Maret 2020 WHO mengumumkan bahwa Covid-19 dinyatakan sebagai pandemi. Pandemi Covid-19 ini berdampak pada semua sektor kehidupan, tak terkecuali pada sektor pendidikan. Akibat dari pandemi ini, kegiatan sekolah mulai dari PAUD hingga perguruan tinggi ditutup. Keadaan ini membuat pemerintah dan lembaga pendidikan untuk melakukan inovasi agar kegiatan belajar mengajar tetap terlaksana (Pohan, 2020).

Di satu sisi, pelaksanaan kebijakan pendidikan jarak jauh di masa pandemi covid19, merupakan sebuah upaya pencegahan penyebaran covid-19 (Güner et al., 2020), namun di sisi lain, itu berarti berhentinya aktivitas sekolah secara fisik dan tatap muka yang menyebabkan peserta didik sering mengalami masalah seperti kurangnya disiplin diri, materi pembelajaran yang sesuai, atau lingkungan belajar yang baik ketika mereka mengisolasi diri di rumah (Abshir, 2020). Kondisi tersebut semakin mempersulit proses peningkatan dan pemerataan mutu pendidikan di Indonesia (Muttaqin, 2018). Padahal, peningkatan mutu merupakan salah satu tuntutan yang harus dilakukan oleh lembaga pendidikan karena pendidikan yang bermutu akan menghasilkan lulusan yang bermutu. Dengan adanya lulusan yang bermutu, tentu sumber daya manusia akan bermutu.

Dalam kondisi pandemi covid-19, di mana pembelajaran jarak jauh menjadi model pembelajaran yang digunakan oleh hampir seluruh sekolah di Indonesia, telah memunculkan masalah baru bagi para pelaku pendidikan. Pembelajaran jarak jauh memerlukan dukungan teknologi tinggi untuk penyelenggaraannya (Mulyanti et al., 2020). Hal ini menimbulkan masalah tersendiri baik bagi sekolah penyelenggara pendidikan maupun bagi para orang tua, terutama yang tinggal di daerah-daerah terpencil yang belum tersentuh teknologi tinggi maupun listrik. Permasalahan tersebut terutama dalam hal pengembangan prestasi akademik yang semakin sulit untuk dilakukan pembelajarannya maupun pengukuran keberhasilannya (Jilardi Damavandi et al., 2011). Hal tersebut memerlukan kepemimpinan kepala sekolah agar kualitas pembelajaran di musim pandemic covid-19 tetap terjaga(Firdaus \& Aslinda, 2020; Hasim \& Hasanah, 2020)

Banyak hal yang mempengaruhi prestasi akademik siswa secara langsung antara lain skala harapan anak-anak, kepuasan diri dan nilai sub skala pendidikan, dukungan orang tua dari skala belajar anak, sub skala dorongan guru dan pada sub skala tingkat kesulitan subjek (Dukmak \& Ishtaiwa, 2015). Tidak kalah penting dari faktor-faktor tersebut, kepala sekolah yang efektif, yang lebih memperhatikan perencanaan pekerjaan dan tugas khusus serta mengijinkan guru untuk berpartisipasi dalam proses pengambilan keputusan dalam upaya mencapai tujuan sekolah dan memengaruhi kinerja para siswa (Obama et al., 2015). Hal itu disebabkan karena kepala sekolah memiliki tanggung jawab penuh pada proses kegiatan belajar mengajar di sekolah. Kepala sekolah memiliki peran untuk memimpin, mengarahkan dan mengambil kebijakan yang akan dilakukan serta mengawasi tiap proses pembelajaran, terutama pada masa pandemi covid-19, yang mengharuskan mengalihkan pembelajaran tatap muka menjadi pembelajaran jarak jauh(Ali \& Hasanah, 2021).

Pada masa pelaksanaan pembelajaran jarak jauh para pendidik dihadapkan pada permasalahan penggunaan aplikasi pembelajaran, permasalahan pada jaringan internet, dan kesulitan pengelolaan pembelajaran yang efektif (Rigianti, 2020). Para guru harus memilih materi pembelajaran untuk disampaikan kepada siswa melalui daring agar tidak terjadi kesalahpahaman materi antara guru dengan siswa, penilaian 
pada pembelajaran dan kurangnya pengawasan saat belajar. Dengan adanya kendala tersebut, dibutuhkan peran dari kepemimpinan kepala sekolah dalam mengambil kebijakan untuk dapat meningkatkan mutu sekolah (Osreni, 2020)

Kepemimpinan merupakan proses yang dilakuakn oleh seorang pemimpin untuk menggerakkan dan mempengaruhi orang lain agar dapat bekerjasama dalam mencapai tujuan yang telah ditetapkan (Surji, 2014). Literatur menunjukkan bahwa kepemimpinan kepala sekolah adalah salah satu faktor yang sangat penting yang memengaruhi hasil sekolah dan pelajar, termasuk tingkat melek huruf dan berhitung, hasil ujian kelulusan sekolah, dan kemajuan kependidikan menengah dan tinggi (Bush \& Glover, 2016). Pada era 4.0, para kepala sekolah dituntut agar mampu mengembangkan kepemimpinan di sekolah yang efektif sesuai perkembangan zaman (Demina, 2020; Syam et al., 2021).

Kepala sekolah adalah seorang guru yang mendapatkan tugas tambahan agar dapat memimpin sumber daya yang ada pada sekolah untuk mencapai tujuan bersama yang telah direncanakan yaitu menjadikan sekolah yang bermutu (Mataputun, 2018). Hal tersebut diperkuat dengan adanya Peraturan Menteri Pendidikan dan Kebudayaan (Permendikbud) Nomor 6 Tahun 2018 Tentang Penugasan Guru Sebagai Kepala Sekolah. yang dimaksud dengan kepala sekolah adalah guru yang diberi tugas untuk memimpin dan mengelola satuan pendidikan yang meliputi TK, TKLB, SD, SDLB, SMP, SMPLB, SMK, SMA, SMALB, dan Sekolah Indonesia di Luar Negeri. Peran kepemimpinan kepala sekolah yaitu menumbuhkan semangat kerja guru-guru dan mampu mengajak bekerjasama untuk meningkatkan kualitas guru serta kualitas siswa (Musri, 2020). Pada masa pandemi covid-19, setiap kepala sekolah harus lebih kreatif dalam mengembangkan program-program peningkatan mutu sekolah berbasis pendidikan jarak jauh, manajemen jarak jauh, dan teknologi tinggi.

SD Muhammadiyah Karangkajen Yogyakarta, merupakan salah satu sekolah yang berhasil meningkatkan mutu akademik peserta didik pada masa pandemi covid-19.
Penelitian ini bertujuan untuk mengeksplorasi best practices kepemimpinan kepala sekolah dalam meningkatkan mutu akademik siswa di masa pandemi covid-19 di SD Muhammadiyah Karangkajen.

\section{METODE}

Pada penelitian tentang Kepemimpinan Kepala Sekolah Di Masa Pandemi Covid-19 dalam Meningkatkan Mutu Akademik Siswa di SD Muhammadiyah Karangkajen 4 Yogyakarta, penulis menggunakan metode penelitian kualitatif (Cropley, 2019);(Palmer \& Bolderston, 2006). Pengumpulan data menggunakan teknik observasi dan wawancara (Hardavella et al., 2016). Pemilihan metode ini dilakukan karena dalam melakukan analisis data tidak dapat dalam bentuk angka, sehingga penulis mendeskripsikan keadaan yang terjadi di lingkungan sekolah. Penulis menggunakan teknik analisis data dengan menggunakan konsep dari Miles dan Huberman yang meliputi reduksi data, penyajian data dan penarikan kesimpulan (Mardawani, 2020).

\section{HASIL DAN PEMBAHASAN \\ Hasil}

Berdasarkan hasil analisis data diketahui bahwa peranan kepala sekolah dalam kondisi pandemi sangat dibutuhkan di sekolah, sebab kepala sekolah merupakan pucuk pimpinan yang bertanggungjawab untuk menentukan arah perkembangan sekolah agar dapat menjamin mutu pendidikan (Mbogo, 2020). Dalam hal ini, yang dilakukan oleh kepala sekolah SD Muhammadiyah Karangkajen 4 Yogyakarta dalam menjalankan perannya sebagai seorang pemimpin, yaitu:

1. Memastikan bahwa proses belajar mengajar baik secara daring maupun luring dapat berjalan lancar dengan tetap menjaga protokol kesehatan.

2. Menjamin kesehatan guru dan siswa dengan selalu menjaga kesehatan dan menerapkan protokol kesehatan.

3. Menjamin tersedianya alat dan bahan, seperti handsanitaiser, sabun cuci tangan, alat penyemprot, alat cuci tangan di setiap ruangan dan alat kebersihan lainnya.

4. Setiap kebijakan dilaksanakan dan diawasi pelaksanaannya. Dalam hal ini kepala 
sekolah mengawasi setiap kegiatan guru dalam berkomunikasi dengan siswa melalui hp. Dalam pelaksanaan luring, apabila ada guru atau siswa yang bepergian dari luar kota atau memiliki gejala yang mengarah ke covid-19, meminta siswa atau guru untuk isolasi mandiri terlebih dulu.

Kurikulum yang digunakan di SD Muhammadiyah Karangkajen 4 adalah kurikulum 2013. Pada masa pandemi ini kepala sekolah SD Muhammadiyah Karangkajen 4 mengikuti kebijakan pemerintah yaitu menyederhanakan kurikulum 2013 sesuai dengan keadaan dan kebutuhan siswa dan sekolah. Dalam pelaksanaannya, kepala sekolah menentukan strategi perencanaan untuk meningkatkan mutu akademik melalui:

1. Menyusun kurikulum darurat sesuai dengan keadaan lingkungan sekolah dan kebijaksanaan pemerintah serta yayasan Muhammadiyah.

2. Guru membuat rencana pembelajaran kurikulum darurat dengan memprioritaskan pelajaran yang sulit untuk siswa.

3. Menyiapkan pembelajaran yang variatif dan komunikatif.

4. Selalu berkomunikasi dengan wali siswa untuk mendapatkan masukan yang diperlukan.

5. Menjalankan konsultasi materi yang dirasakan sulit untuk siswa dan wali siswa.

6. Mengadakan kunjungan rumah atau home visit bagi siswa yang dipandang aman dari Covid-19.

Pelaksanaan pembelajaran secara daring ini banyak pihak yang merasa jenuh, seperti siwa, orangtua siswa, dan tidak terkecuali guruguru di sekolah. Dalam mengatasi kejenuhan guru, kepala sekolah juga harus melaksanakan perannya sebagai motivator. Yang dilakukan oleh kepala sekolah yaitu selalu memberikan motivasi kepada guru agar semangat guru tidak kendur dan lelah dalam menghadapi situasi ini, mengajak guru untuk selalu berjihad melalui pendidikan karena pandemi ini hanya ujian bagi orang-orang mukmin dan ujian ini akan berakhir, mengajak guru untuk berdiskusi minimal satu kali seminggu untuk menerima masukan dan menyampaikan kesulitan apa saja dalam penyampaian materi kepada siswa serta kendala lainnya, dan kepala sekolah juga selalu berusaha mencukupi kebutuhan guru untuk pelaksanaan pembelajaran, memperluas daya jangkau WIFI agar guru tidak mengeluarkan biaya sendiri untuk membeli kuota dan mencairkan dana bantuan untuk pembelian pulsa guru.

Untuk mensukseskan hasil pembelajaran pada masa pandemi ini, dibutuhkan dukungan dari wali siswa, dewan sekolah, yayasan, dan pemerintah pusat. Dibutuhkan semangat yang besar dari guru dan wali siswa untuk selalu ingin memajukan pendidikan dengan baik, adanya kesadaran seluruh warga sekolah untuk dapat memberikan pelayanan yang terbaik untuk siswa, serta sarana dan prasarana yang nyaman untuk guru di sekolah.

Pada kenyataanya, walapun banyak dukungan dari berbagai pihak, tetap saja muncul beberapa hambatan dalam pelaksanaan pembelajaran daring ini, diantaranya adalah kurangnya dukungan berupa dana dari yayasan, keterlambatan BOS dan BOP, kurang pahamnya wali terhadap kewajibannya yang menimbulkan banyak tanggungan SPP yang tidak terbayar serta kekhawatiran dari berbagai pihak juga mengenai penularan covid-19.

Pandemi Covid-19 membuat pelaksanaan pendidikan benar-benar berubah. Banyak pihak yang belum siap dengan keadaan berubah secara mendadak ini. Pembelajaran daring membawa kejenuhan siswa untuk belajar secara mandiri di rumah.

Pada awal masa pandemi Covid-19, SD Muhammadiyah Karangkajen 4 Yogyakarta melakukan pembelajaran secara daring. Pembelajaran daring adalah pembelajaran yang dilakukan dengan tidak melakukan tatap muka, pembelajaran menggunakan jaringan internet dengan bantuan aplikasi seperti google classroom, google meet, zoom, whatsapp dan lain sebagainya. Faktanya, banyak terjadi kendala, diantaranya adalah terbatasnya handphone atau perangkat teknologi yang dimiliki siswa, terbatasnya kuota, banyak wali siswa mengeluhkan tidak mampu mendampingi belajar anaknya, beberapa anak juga malah cenderung bermain di luar rumah. Guru juga mengeluhkan mulai bertambah jumlah siswa yang tidak mengumpulkan tugas. 
Efek dari pembelajaran dari rumah secara daring yaitu menurunnya mutu akademik siswa. Beberapa penyebabnya yaitu waktu kegiatan belajar mengajar dengan guru menjadi terbatas, tidak semua anak maupun orangtua mampu menggunakan IT, mata pelajaran yang diberikan dan diterima oleh siswa hanya tertentu dan terbatas.

Untuk mengatasi penurunan mutu akademik siswa, kepala sekolah melakukan sebuah kebijakan, yaitu membuka pelayanan pembelajaran di sekolah. Tentunya dengan berbagai pertimbangan dan mematuhi protokol kesehatan (cek suhu tubuh, cuci tangan, memakai masker, mengatur jarak antar teman dan guru, serta pembatasan jumlah siswa yang melakukan tatap muka) dan memberlakukan persyaratan untuk peserta didik, seperti siswa yang hadir ke sekolah harus sehat (tidak demam, flu, maupun batuk), selalu memakai masker, tidak dari perjalanan luar kota dan dipastikan keluarganya tidak ada yang terkena covid-19. Guru dan karyawan di sekolah juga dipastikan bahwa keluarganya tidak ada yang terkena covid-19. Juga bekerjasama dengan puskesmas terdekat.

Terbukti dengan diadakannya pelayanan tatap muka, mutu akademik siswa kembali meningkat, karena kesulitan-kesulitan materi yang dirasakan di rumah dapat dikonsultasikan secara langsung dengan guru-guru di sekolah. Siswa semangat untuk belajar, nilai akademik siswa juga kembali meningkat dan siswa lebih bertanggungjawab dalam mengerjakan tugastugasnya. Beban orangtua seperti harus mengajari atau mengawasi anak saat belajar dan biaya kuota juga menjadi berkurang.

Sekolah tetap mengadakan evaluasi pembelajaran siswa secara daring (pemberian tugas melalui google classroom) maupun luring (mengerjakan soal langsung di sekolah). Secara ringkas, kepemimpinan kepala sekolah dalam meningkatkan nilai akademik siswa pada masa pandemic covid-19 dapat dilihat dalam tabel 1 berikut ini:

Tabel 1. Peran kepemimpinan kepala sekolah dalam meningkatkan mutu akademik

\begin{tabular}{|l|l|}
\hline $\begin{array}{l}\text { Aspek } \\
\text { kepemimpinan }\end{array}$ & Tindakan kepemimpinan \\
\hline $\begin{array}{l}\text { Memastikan } \\
\text { PBM berjalan }\end{array}$ & $\begin{array}{l}\text { Menyusun kurikulum darurat } \\
\text { Guru wajib Menyusun rencana }\end{array}$ \\
\hline
\end{tabular}

\begin{tabular}{|l|l|}
\hline lancar & $\begin{array}{l}\text { pembelajaran jarak jauh } \\
\text { Guru wajib melaksanakan } \\
\text { pembelajaran yang variative } \\
\text { Memberikan pelayanan home visit }\end{array}$ \\
\hline $\begin{array}{l}\text { Menjamin } \\
\text { Kesehatan } \\
\text { semua pihak }\end{array}$ & $\begin{array}{l}\text { Menyediakan sarana Kesehatan } \\
\text { untuk antisipasi penyebaran virus }\end{array}$ \\
\hline $\begin{array}{l}\text { Melakukan } \\
\text { prinsip } \\
\text { manajemen } \\
\text { mulai dari } \\
\text { perencanaan, } \\
\text { pelaksanaan, } \\
\text { dan evalusi }\end{array}$ & $\begin{array}{l}\text { Merencanakan dan mengawasi } \\
\text { pelaksanaan program secara terus }\end{array}$ \\
\hline
\end{tabular}

Sumber: Hasil pengolahan data penelitian

\section{Pembahasan}

Hasil penelitian menunjukan bahwa kepala sekolah telah melaksanakan berbagai tidnakan kepemimpinan dalam upaya peningkatan nilai akademik siswa pada masa pendemi covid-19. Dalam hal ini, kepala sekolah telah berupaya menerapkan prinsip kepemimpinan sekolah sebagaimana disebutkan oleh Sagala (Sagala, 2018) bahwa proses Kepemimpinan adalah seseorang yang mempunyai wewenang, pengikut dan memilikik kemampuan mempengaruhi dan meyakinkan orang lain untuk melakukan sesuatu dengan penuh tanggung jawab serta membuat keputusan untuk mencapai tujuan suatu organisasi yang sesuai dengan visi dan misi organisasi. Kepemimpinan kepala sekolah adalah sebuah kemampuan yang dimiliki oleh seorang tenaga fungsional guru yang mendapatkan tugas tambahan untuk memimpin sebuah sekolah untuk menggerakan berbagai sumber daya yang ada di sekolah agar dapat diberdayakan secara maksimal untuk mencapai tujuan yang telah ditetapkan (Rachmawati, 2013).

Berbagai kebijakan berupa upaya untuk memastikan terjaminnya kelancaran PBM dengan melakukan proses penjaminan kesehatan guru dan siswa menunjukan bahwa kepala sekolah memiliki sikap adaptif dan siap untuk mengikuti perubahan. Ini adalah sikap kepemimpinan yang sangat dibutuhkan dalam kondisi pandemic seperti sekarang, sebagaimana dikatakan oleh Huntsman, dkk. (Huntsman et al., 2021) bahwa ketajaman untuk menangani kondisi kompleks, di mana perubahan konstan diperlukan. Sejalan dengan 
itu, dalam lingkungan bencana yang kompleks, diperlukan sikap adaptif agar mampu menjadi organisasitanggap darurat. Kemampuan adaptasi pemimpin yang tidak terlalu kaku dalam melaksanakan aturan, prosedur, dan kebijakan dalam organisasi hierarki dalam masa bencana yang kompleks merupakan suatu kebutuhan organisasi.

Menyusun kurikulum darurat. Kepala sekolah bersama-sama dengan para guru menyikapi kondisi perkembangan dunia pendidikan di masa covid dengan cara menyusun kurikulum darurat. Dalam kurikulum darurat, dikaji esensi dari setiap mata pelajaran yang memungkinkan untuk diajarkan secara efektif melalui pembelajaran jarak jauh. Pengkajian esensi kurikulum adalah tindakan kepemimpinan yang efektif untuk mengatasi permasalahan yang muncul dalam praktik pembelajaran jarak jauh. Hal itu sejalan dengan hasil penelitian bahwa meskipun banyak faktor yang dapat memengaruhi hasil pendidikan pasca pandemic covid-19, namun aspek kurikulum merupakan hal yang sangat penting dipikirkan penyesuaiannya. Pihak sekolah tidak dapat menghinda dari adanya perubahan habit dan situasi pendidikan pada masa covid-19 maupun setelahnya.

Penyusunan RPP yang sesuai dengan kurikulum darurat. Guru menyusun rencana pembelajaran berdasar kurikulum darurat dengan memprioritaskan pada materi pelajaran yang sulit. Tentunya guru harus memperhatikan beberapa aspek, seperti bagaimana kemampuan siswa dan orang tua, dalam penyusunan RPP perlu diperhatikan juga apakah media yang akan digunakan untuk mendukung pembelajaran juga tersedia di rumah para siswa. Untuk menyusun penilaian dalam RPP, guru melibatkan orang tua siswa agar mereka juga dapat mengetahui sejauh mana pencapaian anaknya dan efektivitas dukungan dari mereka.

Pembelajaran yang variatif dan komunikatif. Guru menyiapkan pembelajaran yang variatif, siswa tidak hanya mengerjakan tugas menggunakan LKS atau lembar kerja, tetapi diberi tugas untuk menggambar, bernyanyi dan bahkan belajar di luar ruangan. Dapat juga diberikan kegiatan yang dapat membangun kognitif dan nonkognitif. Guru dan kepala sekolah juga menjaga komunikasi yang baik dengan orang tua siswa. Orang tua siswa dilibatkan dalam penyusunan rancangan pembelajaran. Hal ini dapat memberikan kesempatan kepada orang tua siswa untuk memberikan masukan berupa kegiatan dan media apa saja yang dapat digunakan di rumah yang tentu saja sesuai dengan sumber daya yang mereka miliki. Dengan adanya komunikasi yang baik antara pihak sekolah dengan orang tua, akhirnya orang tua juga memiliki kesiapan untuk mendukung anaknya dalam belajar.

Pelayanan untuk materi-materi sulit. Dalam proses belajar di rumah, banyak siswa memiliki keterbatasan dalam memahami materi-materi yang diberikan secara daring, bahkan orang tua juga ada yang merasa kesulitan dalam mendampingi anaknya untuk memahami materi yang diberikan guru. Maka dari itu, kepala sekolah membuka fasilitas pelayanan untuk materi-materi yang sulit melalui pelayanan konsultasi baik secara daring (dengan aplikasi whatsapp atau video call), maupun tatap muka di sekolah.

Home Visit. Dalam mendukung terlaksananya pembelajaran, guru juga melaksanakan home visit dengan mendatangi rumah siswa yang dipandang aman dari Covid19 secara bergantian. Hal ini dapat membangun komunikasi yang lebih baik dengan siswa dan orang tuanya, menjadi motivasi belajar untuk siswa. Bila siswa ada yang kesulitan dalam belajar, dengan kunjungan inilah siswa dapat bertanya langsung dengan gurunya.

Untuk meyakinkan bahwa semua program peningkatan nilai akdemik siswa, dapat berjalan dengan baik, kepal sekolah melakukan pengawasan secara online. Hal ini menunjukan adanya pemahaman dan kesadaran dari pimpinan sekolah bahwa tugas pemimpin adalah memberikan jaminan bahwa proses pelayanan pendidikan berjalan sebagaimana mestinya. Hal ini menegaskan bahwa kepala sekolah harus memiliki pengetahuan dan keterampilan untuk dapat memimpin organisasi dalam konteks sekolah apapun (Yongmei Ni, Liz Hollingworth, Andrea Rorrer, 2016). Hal itu diperkuat dengan hasil penelitian Sukasman (Sukasman, 
2020) yang menyatakan bahwa pengawasan berfungsi untuk meningkatkan kualitas guru. Secara tidak langsung, jika kualitas guru meningkat, maka kualitas mutu akademik siswa akanmeningkat.

\section{KESIMPULAN DAN REKOMENDASI}

Kepala sekolah harus mampu melaksanakan perannya dengan baik, untuk dapat mengambil keputusan dengan cepat dan tepat dalam proses membangun mutu pendidikan terlebih di masa pandemic covid19 yang telah memaksa semua siswa melaksanakan pembelajaran jarak jauh.

Untuk mengatasi adanya penurunan mutu akademik siswa sebagai efek perubahan model pembelajaran di skeolah saat pandemic, kepala sekolah SD Muhammadiyah Karangkajen 4 Yogyakarta membuka layanan konsultasi belajar tatap muka di sekolah. Tentunya tetap dengan menjalankan protokol kesehatan bagi semua siswa dan warga sekolah. Dengan dibukanya layanan belajar tatap muka ini, mutu akademik siswa mulai meningkat lagi.

\section{KEPUSTAKAAN ACUAN}

Abshir, B. A. (2020). The Effect of Coronavirus ( COVID-19) on Face to Face Learning of Undergraduate Students in Mogadishu, Somalia. International Journal of Education and Social Science, 7(5), 21-32.

Ali, S., \& Hasanah, E. (2021). Kepemimpinan Kepala Sekolah dalam Menjamin Mutu Pendidikan Pada Masa Pandemi Covid19 di SMA Muhammadiyah 3 Yogyakarta. Jurnal Ilmiah Mandala Education, 7(1).

Bush, T., \& Glover, D. (2016). School leadership and management in south africa: findings from a systematic literature review. International Journal of Educational Management, 30(2), 211-231.

Cropley, A. (2019). Qualitative research methods: A practice-oriented introduction forstudents of psychology and education (2ndupdated ed.). Zinātne. https://doi.org/10.13140/RG.2.1.3095. 6888

Demina, D. (2020). Leadership management of education and personality leaders of industrial revolution 4.0. Al-Fikrab: Jurnal Manajemen Pendidikan, 8(2). https://doi.org/10.31958/jaf.v8i2.2616

Dukmak, S., \& Ishtaiwa, F. F. (2015). Factors Influencing the Academic Achievement of Students in the Preparatory and Secondary Schools of the United Arab Emirates. European Journal of Social Science, 46(January 2015), 132-148.

Firdaus, A., \& Aslinda, A. (2020). Strategi pengembangan manajemen peserta didik dalam meningkatkan mutu pendidikan di mtsn padang panjang. Al-Fikrab: Jurnal Manajemen Pendidikan, 8(2). https://doi.org/10.31958/jaf.v8i2.2260

Güner, R., Hasanoğlu, İ., \& Aktaş, F. (2020). Covid-19: Prevention and control measures in community. Turkish Journal of Medical Sciences, 50(SI-1), 571-577. https://doi.org/10.3906/sag-2004-146

Hardavella, G., Aamli Gagnat, A., Xhamalaj, D., \& Saad, N. (2016). How to prepare for an interview. Breathe, 12(3), e86-e90. https://doi.org/10.1183/20734735.0137 16

Hasim, W., \& Hasanah, E. (2020). The Role of Principal Leadership in Preventing COVID-19 Transmission at SMA Muhammadiyah 2 Karang Tengah Buay Madang Timur Indonesia. Asian Journal of Education and Social Studies, 11(1), 1-10. https://doi.org/10.9734/ajess/2020/v1 $1 \mathrm{i} 130279$

Huntsman, D., Greer, A., Murphy, H., \& Haynes, S. (2021). Enhancing adaptive performance in emergency response: Empowerment practices and the moderating role of tempo balance. Safety Science, 134(December 2020), 105060. https://doi.org/10.1016/j.ssci.2020.105 060

JilardiDamavandi, A., Mahyuddin, R., Elias, H., Daud, S. M., \& Shabani, J. (2011). Academic Achievement of Students with Different Learning Styles. International Journal of Psychological Studies, 3(2). https://doi.org/10.5539/ijps.v3n2p186

Mardawani. (2020). Praktis Penelitian Kualitatif Teori Dasar dan Analisis Data dalam Perspektif Kualitatif. Deepublish.

Mataputun, Y. (2018). Kepemimpinan Kepala 
Sekolah Berbasis Kecerdasan Intelektual, Emosional, dan Spiritual Terbadap Iklim Sekolah (Fungky (ed.)). Uwais Inspirasi Indonesia.

Mbogo, R. W. (2020). Leadership Roles in Managing Education in Crises: the Case of Kenya During Covid-19 Pandemic. European Journal of Education Studies, 7(9), 207-227.

https://doi.org/10.46827/ jes.v7i9.3250

Mulyanti, B., Purnama, W., \& Pawinanto, R. E. (2020). Indonesian Journal of Science \& Technology Distance Learning in Vocational High Schools during the COVID-19 Pandemic in West Java Province, Indonesia. Indonesian Journal of Science \& Technology, 5(2), 271-282.

Musri, M. (2020). Peran kepemimpinan kepala sekolah terhadap kedisiplinan guru dan karyawan di smp negeri 8 padang. Jurnal Ilmiah Ekotrans \& Erudisi, 1, 33-45.

Muttaqin, T. (2018). Determinants of Unequal Access to and Quality of Education in Indonesia. Jurnal Perencanaan Pembangunan: The Indonesian Journal of Development Planning, 2(1), 1-23. https://doi.org/10.36574/jpp.v2i1.27

Obama, M. O., Eunice2, L. A., \& Orodho, J. A. (2015). Effect of Principals' Leadership Styles on Students Academic Performance in Public Secondary Schools in Homa-Bay County, Kenya. IOSR Journal Of Humanities And Social Science Ver. VII, 20(3), 51-60. https://doi.org/10.9790/083720375160

Osreni, O. (2020). Peran gaya kepemimpinan kepala sekolah dalam meningkatkan kinerja guru dan mutu sekolah (studi kasus di sd negeri 02 batipuh kecamatan batipuh selatan). Al-Fikrah: Jurnal Manajemen Pendidikan, 8(1), 29. https://doi.org/10.31958/jaf.v8i1.1715

Palmer, C., \& Bolderston, A. (2006). A Brief Introduction to Qualitative Research.
Canadian Journal of Medical Radiation

Technology, $\quad 37(1), \quad$ 16-19.

https://doi.org/10.1016/s0820-

5930(09)60112-2

Pohan, albert efendi. (2020). Konsep Pembelajaran Daring Berbasis Pendekatan Imiah. CV. Sarnu Untung.

Rachmawati, Y. (2013). Pengaruh Kepemimpinan Kepala Sekolah Terhadap Kinerja Guru. Jurnal Pendidikan Ekonomi IKIP Veteran Semarang, 01, 1928.

Rigianti, H. A. (2020). Kendala pembelajaran daring guru sekolah dasar di kabupaten banjarnegara. Elementary School 7, 7, 297302.

Sagala, S. (2018). pendekatan dan Model Kepemimpinan. Prenadamedia Group.

Sukasman, S. (2020). Supervisi Akademik Berkelanjutan Untuk Meningkatkan Kompetensi Pedagogik Guru Dalam Menyusun Rencana Pelaksanaan Pembelajaran. Edukasi: Jurnal Pendidikan, 18(1), 28. https://doi.org/10.31571/edukasi.v18i1 .1752

Surji, K. (2014). Understanding Leadership and Factors that Influence Leaders' Effectiveness. European Journal of Business and Management, January 2015. https://doi.org/10.7176/ejbm/7-332015-03

Syam, R. Z. A., Sauri, R. S., \& Indah, R. N. (2021). Strategi peningkatan mutu lulusan prodi paud melalui pelaksanaan sistem penjaminan mutu internal di universitas islam nusantara. Al-Fikrah: Jurnal Manajemen Pendidikan, 8(2). https://doi.org/10.31958/jaf.v8i2.2415

Yongmei Ni, Liz Hollingworth, Andrea Rorrer, and D. P. (2016). The evaluation of educational leadership preparation programs. In Handbook of research on the education of school leaders (pp. 285-307). Routledge. https://doi.org/15031-0153 